\title{
Andrej Sládkovič v chorvátskej recepcii Marijan Šabić
}

\author{
ŠABIĆ, M.: Andrej Sládkovič in Croatian reception \\ SLOVENSKÁ LITERATÚRA 68, 2021, No. 2, p. 145-153 \\ DOI: https://doi.org/10.31577/slovlit.2021.68.2.6 \\ ORCID ID: 0000-0003-3095-2363
}

\begin{abstract}
Key words: Slovak-Croatian literary and cultural relations, Andrej Sládkovič, literary translation, Luko Paljetak, Dubravka Dorotić Sesar
\end{abstract}

The article is a contribution to the research of Slovak-Croatian literary and cultural relations. It focuses at the reception of Andrej Sládkovič (1820 - 1872) in the Croatian context. The second half of the 19th-century is investigated through the analysis of contributions to Croatian literary magazines and newspapers such as Danica, Dragoljub, Vienac, Slavonac and Nada. The analysis of the 2oth-century and contemporary reception looks at texts published in various magazines, books and anthologies which contain translations by Luko Paljetak, Dubravka Dorotić Sesar and others. Since Sládkovič did not have any personal contacts with Croatian intellectuals of the time, the presence of his work in the 19th-century Croatian cultural space was scarce. Wider recognition of his oeuvre came much later and in the late 2oth-century, it was intensified by the establishment of a Slovak studies programme at the University of Zagreb (as part of Czech studies in 1994 and as a separate programme in 1997). While in the 19th century, period magazines and newspapers - albeit sporadically-do mention Sládkovič, but do not contain any translations of his work, nowadays, translations are available, but are usually only known in the narrow academic circles of (mainly) Slavic studies experts.

Klúčcové slová: slovensko-chorvátske literárne a kultúrne vzt'ahy, Andrej Sládkovič, umelecký preklad, Luko Paljetak, Dubravka Dorotić Sesar 
horvátske literárne časopisy plnili v 19. storočí viacero zásadných úloh: v kontexte sociologického pohl'adu na literatúru vytvárali podmienky pre rozvoj literárneho (knižného) trhu, utvárali literárne publikum, formovali dobový čitatel'ský vkus. V oblasti poetiky literatúry mali dosah na osvojovanie si nových žánrov, štýlov a postupov. Práve literárne časopisy boli platformou aktuálne nastupujúcej chorvátskej literatúry (Brešić 2005:13-14). Zároveň boli hlavným médiom recepcie zahraničných literatúr, teda aj slovenskej a českej.

Chorvátskych literárnych časopisov nebolo v 19. storočí vel'a a možno ich rozdelit' do troch skupín. Prvú skupinu predstavujú tzv. zábavno-výchovné časopisy, ktoré sa obracali na širší okruh čitatel'ov - intelektuálov, vzdelaných meštanov, no takisto všetkých, ktorí vedeli čítat' a ktorých čitatel'ský apetít už nedokázali uspokojit' ludové kalendáre. Od roku 1835, ked'začala vychádzat'Danica, redakčne pripravovaná Ljudevitom Gajom, pôsobil v pozícii ústredného periodika až do roku 1903 aspoň jeden takýto časopis, pričom jednotlivé redakcie si daný status akoby navzájom odovzdávali. ${ }^{1} \mathrm{~V}$ druhej skupine, medzi regionálne koncipovanými literárnymi časopismi, vynikali Zora dalmatinska (1844-1849) a Slavonac (1863-1865), osobitný status mal však časopis Nada (1895-1903), ktorý založila Zemská vláda pre Bosnu, aby afirmovala bosniansku národnost', hoci jeho väčšinovými spolupracovníkmi boli chorvátski autori. Ako tretiu skupinu možno vyčlenit' literárne časopisy, ktoré mali elitnú, vedeckú a filologickú povahu a vychádzali zriedkavejšie, napríklad Kolo (1842-1853) a Književnik (1864-1866).

Kým časté a kontinuálne zastúpenie českej kultúry a literatúry na stránkach chorvátskych literárnych časopisov 19. storočia mohlo byt' spracované monograficky (Šabić 2007; Šabić 2008), recepciu slovenskej literatúry zhrnul iba väčší prehl'adový článok Dubravky Sesar (Dorotić Sesar 1998). Podl'a autorkinej analýzy obsahovali najväčší počet slovenských referencií spomedzi chorvátskych časopisov v 19. storočí Danica a Vienac. V Danici, vychádzajúcej v štyridsiatych a pät'desiatych rokoch 19. storočia, prevládal filologický a všeobecne kultúrny záujem o slovanské prostredie, a preto boli medzi slovenskými autormi najviac zastúpení Ján Kollár, Pavol Jozef Šafárik a L'udovít Štúr. Vienac, časovo zasadený do poslednej tretiny 19. storočia, sa orientoval viac na rozvíjanie domácej modernej literatúry a na preklady diel súvekých zahraničných autorov. Hoci i Vienac venoval určitú pozornost' dielu a názorom slovenských tvorcov staršej generácie, ako boli J. Kollár, Jozef Miloslav Hurban a Michal Miloslav Hodža, rovnako ako Danica nesledoval poéziu ich spolupútnikov (teda ani Andreja Sládkoviča). Vo Vienci sú prekladmi zastúpení Ján Kalinčiak, L'udovít Kubáni, Svetozár Hurban-Vajanský, Elena Maróthy-Šoltésová, vyšli tam tiež medailóny života a tvorby Pavla Országha Hviezdoslava a E. Maróthy-Šoltésovej (Dorotić Sesar 1998: 73-84). Na druhej strane, slovensko-chorvátske kultúrne vztahy v 19. storočí, najmä v období národného obrodenia, boli síce dost' intenzívne, no ani slovenské literárne časopisy neprinášali vo väčšej miere prílohy z chorvátskej literatúry (tento stav možno badat' aj v prvom zväzku obsiahlej monografie Jána Jankoviča o chorvátsko-slovenských literárnych vztahoch; Jankovič 1997).

1 V chronologickom poradí najdôležitejšie zábavno-výchovné literárne časopisy v období, v ktorom vychádzali, boli:Danica (1835 - 1849), Neven (1852 - 1858), Naše gore list (1861 - 1866), Dragoljub (1867 -1868) a Vienac (1869-1903). 
Na otázku, aké boli vztahy A. Sládkoviča s Chorvátmi, možno odpovedat' jedným slovom: nepriame. Napísal epos o Mikulášovi Šubičovi Zrínskom, v ktorom na niekol'kých miestach zdôrazňuje chorvátsky pôvod a vlast' sihotského hrdinu, bol vel'kým ctitel'om biskupa Moysesa, ktorý približne dvadsat' rokov pôsobil v Záhrebe a mal tu vel'ký vplyv. Pravdepodobne práve biskup Moyses ho podnietil k napísaniu epickej básne, ktorá ani poeticky, ani žánrovo nezapadala do jeho dovtedajšieho opusu. ${ }^{2}$ Sládkovič nepoznal osobne vel'a Chorvátov. Ak sa pozrieme do zoznamu Sládkovičovej rozsiahlej korešpondencie so súčasníkmi, nenájdeme v nej ani jedno chorvátske meno (Kraus 1970). V Literárnom archíve Slovenskej národnej knižnice v Martine je uložený len jediný list chorvátskeho pisatel'a adresovaný A. Sládkovičovi: v liste z 13. októbra 1867 prosil Abel Lukšić z Viedne básnika o životopis a jeho portrét, aby ich mohol začlenit' do pripravovaného albumu významných Slovanov. ${ }^{3}$

$\mathrm{V}$ chorvátskych literárnych časopisoch z 19. storočia môžeme nateraz registrovat' iba tri preklady Sládkovičových básní z jeho inak rozsiahleho diela. ${ }^{4}$ Dve preložené básne boli uverejnené v časopise Slavonac, ktorý vychádzal v meste Požega, v čísle z februára 1864. Tento regionálne koncipovaný časopis nebol bezvýznamný, publikovali v ňom viacerí kvalitní a dôležití chorvátski literáti daného obdobia (August Šenoa, Petar Preradović, Mirko Bogović) a priniesol aj preklady z diel Johanna Wolfganga Goetheho, Heinricha Heineho, Adama Mickiewicza či Alexandra Sergejeviča Puškina. Je predpoklad, že obidve Sládkovičove básne preložil Miroslav Kraljević, redaktor a vydavatel' časopisu Slavonac (Jankovič 2002: 86). Prvá báseň, Na hrobe materi (Sládkovič 1864a), bola v origináli zveršovaná práve podl'a verzifikačného modelu, ktorý si pri preklade Sládkovičovej Maríny všimol Luko Paljetak: ide o zámeny párnych desat'slabičných veršov (5 +5) jambického impulzu s trojstopovými osemslabičnými veršami nedôsledne usporiadaných slabík (Paljetak 2005a: 151-152). Chorvátsky prekladatel'ponechal štvorveršie, ponechal rým $a b a b$, ale verš preloženej básne prispôsobil veršu domácej ludovej poézie, pričom dôsledne používal desat'slabičný verš $4+6$ a zväčša osemslabičný verš $4+4$. Podobne sa dá povedat' aj o spôsobe, ktorým bola pôvodne napísaná a preložená báseň Prosba, uverejnená v časopise Slavonac o dve čísla neskôr (Sládkovič 1864b). Podobnost' vo veršovaní nie je to jediné, čo spája tieto dve básne, sú späté aj obsahovo. V prvej básni dcéra na hrobe matky hovorí zosnulej, že môže pokojne spat', lebo dcéra si nesie do života všetko, čo ju matka naučila, v druhej snúbenec prosí svoju milú, aby mu spievala slovanské piesne, ktoré spievala aj jej matka. Tretia Sládkovičova báseň, ktorá bola preložená do

2 Na špecifické postavenie eposu o Zrínskom v Sládkovičovom opuse, ako aj na pravdepodobnost' toho, že na jeho vznik mal vplyv práve Moyses, upozornila Dubravka Dorotić Sesar v referáte Stjepan Moyses i obnova kulta Nikole Šubića Zrinskog, prednesenom na vedeckej konferencii k 220. výročiu narodenia Štefana Moysesa, ktorá sa uskutočnila v Záhrebe 3. februára 2018. Vydanie konferenčného zborníka sa aktuálne pripravuje.

3 Slovenská národná knižnica v Martine, Literárny archív, osobný fond Braxatoris-Sládkovič, Andrej, list Abela Lukšića Andrejovi Sládkovičovi, sign. M 94 A 52.

4 J. Jankovič predpokladal, že v roku 1868 , „časopis Dragoljub uverejnil ukážky zo Sládkovičovej poézie v preklade Stjepka Spanića (pseudonym Ferdinando Plohl)“ (Jankovič 1997: 86). Pri rešeršovaní tohto ročníka časopisu Dragoljub som nenašiel žiadny preklad zo Sládkoviča. Rikardo Ferdinando Plohl-Hedvigov tam uverejnil jeden sonet z Kollárovej knihy Slávy dcéra, pod názvom Marinki. Sonet iz „Slavy dcere“ (Kollár 1868). 
chorvátčiny, nesie v origináli názov Pieseň, ale v preklade má názov Elegija (Sládkovič 1895). Dňa 15. marca 1895 ju vydal Josip Milaković v sarajevskom časopise Nada, ktorý redigoval jeho priatel'Silvije Strahimir Kranjčević, a rovnaký preklad básne neskôr zaradil do svojej zbierky preloženej poézie Iz slavenskih lugova, vydanej v Záhrebe v roku 1909. Navyše, J. Milaković preložil pre časopis Nada aj mnohé české básne, no tiež jednu báseň Vajanského a Hviezdoslava. Pri preklade Sládkovičovej básne Pieseň sa Milaković usiloval držat' čo najviac originálneho verša a báseň preložil podl'a pôvodnej schémy, t. j. oktávami zloženými zo skrížene rýmovaných osemslabičných veršov $4+4$ a sedemslabičných veršov $4+3$. Všetky tri uvedené Sládkovičove básne boli zaradené vo vydaní Spisy básnické z roku 1861, ked'že však básne Na hrobe materi a Pieseň tam boli uverejnené prvý raz, možno usudzovat', že práve toto slovenské vydanie Sládkovičovej poézie tvorilo základ skromnej chorvátskej recepcie jeho diela v 19. storočí.

Je zjavné, že Sládkovič nebol v 19. storočí vel'mi prekladaný do chorvátskeho jazyka. To však neznamená, že chorvátski literáti a chorvátska intelektuálna verejnost', hoci iba v malom počte, nevedeli, aký význam mal pre vtedajšiu slovenskú literatúru i pre slovenský literárny kánon. Dokazuje to nielen spomenutý Lukšićov list Sládkovičovi, ale predovšetkým články uverejnené v chorvátskych časopisoch.

Danica ilirska priniesla v marci 1864 úryvok z tretieho zväzku Viktorinovho zábavníka Lipa. Autor článku podpísaný ako Mirogojski považuje dve do neho zaradené Sládkovičove básne (rozsiahlejšiu lyricko-epickú skladbu Lipa cyrilo-metodejská a kratšiu Až posial'! A d'alej?, dedikovanú samotnému edičnému podujatiu) za „perly zábavníka“, pričom o Sládkovičovi píše ako o „prvom slovenskom lyrickom básnikovi“ a chváli jeho básnickú zdatnost' a originálnost' jeho poézie. Súčastou článku je tiež preklad prvej oktávy Sládkovičovej básne $A z ̌$ posial'! A d'alej? (Mirogojski 1864). Rovnaké vydanie slovenského zábavníka Lipa evidoval aj časopis Slavonac, ktorého redaktorom bol M. Kraljević. Nepodpísaný autor síce polemicky nadväzuje na vyššie uvedený článok z Danice, no tento polemický tón opúšta práve pri hodnotení Sládkovičovho prínosu a pri všeobecnom ocenení jeho literárneho diela. Sládkoviča nazýva „ovenčeným tatranským básnikom“, cituje dve posledné štvorveršia rovnakej básne, ktorú citoval Mirogojski v Danici, a pripomína, že Lipa cyrilo-metodejská je „nadaná, ako najvýnimočnejší kúsok celej tohtoročnej Lipy“ (Lipa 1864).

Viac pozornosti venoval Sládkovičovi Šenoov Vienac, ale až po jeho smrti: 10. augusta 1872 priniesol krátky prehl'ad Sládkovičovho života a jeho najdôležitejších diel (Slavni slovački pjesnik 1872). Koncom 19. a začiatkom 20. storočia, v čase generačných nezhôd na chorvátskej literárnej scéne, sa Vienac popri Prosvjete stal tribúnou staršej generácie literátov, ktorá sa ostro postavila proti modernistickým a dekadentným tendenciám. Takéto konzervatívne ladenie mala aj informácia o martinskom vydaní prvého zväzku Sládkovičových zozbieraných básnických diel z roku 1899, do ktorého boli zahrnuté skladby Marína, Detvan, Milica, poéma Svätomartiniáda a historická epická báseň Gróf Mikuláš Šubić Zrínsky na Sihoti (Sládkovič 1899):

„Niet pochýb, že slovenský národ teraz s radostou privinie zozbierané básnické diela Andreja Sládkoviča, pretože so zvukom toho mena sa spája tol'ko 
sladkého v duši každého Slováka, v starších prebúdza ,spomienky krajších dní, v mladších romantické nadšenie. Pred očami opätovne ožíva vedomie minulých dôb, počut zurčanie milých a večne mladých melódií a čitatel'sa duchom prenesie do vyšších, čistejších sfér, do nejakej duševnej slobody bez svojvôle, do krajov ideálov bez snov a vidín. To je čistý svet, v ktorom sa hýbe Sládkovičova poézia, a tento svet je Slovákom známy, blízky, reálny, pravdivý. V ňom je zrelý pocit, a nie nezdravá sentimentálnost', živá fantázia, a nie fantastická neurčitost', ale nádej, že všetky charaktery a obrazy, ktorým dal život, preniesol z tvorivej fantázie do skutočného sveta. V tom sa Sládkovič podobá na Puškina, tvorcu a reformátora novšej ruskej literatúry. Sládkovičove básne sú také plné a bohaté na básnické skvosty, že čitatel' neustále nachádza novosti a objavuje nové hviezdy, ktoré si na prvý pohlad vôbec nevšimol“ (Pjesme Andreja Sladkovića 1899).

O vydaní druhého zväzku Sládkovičových zozbieraných básnických diel uverejnil Vienac iba kratšiu správu (Pjesme Andrije Sladkovića 1901). Spomenuté tri texty (z rokov 1872, 1899 a 1901) sú všetko, čo tento dlhoročný chorvátsky literárny časopis predkladá svojim čitatel'om o Sládkovičovi.

Na základe doteraz zozbieraných informácií sa dá konštatovat', že Sládkovičova poézia bola v chorvátskych časopisoch 19. storočia riedko prekladaná, vychádzal o ňom malý počet textov, no i na tejto menšej vzorke vidiet', že chorvátska kultúrna verejnost'vedela o význame jeho diela pre vtedajšiu slovenskú literatúru a tiež o povesti, ktorú mal medzi slovenskými literátmi a čitatel'mi. Sládkovičova chorvátska recepcia $\mathrm{v}$ 19. storočí bola tak rovnako nepriama, ako boli nepriame jeho osobné vztahy s Chorvátskom a Chorvátmi. V rovnakej rovine pokračovala aj v medzivojnovom období, predovšetkým prostredníctvom prác všestranného polyglota a slavistu Ivana Esiha, ktorý najmenej dva razy písal o Sládkovičovej Zríniáde (Esih 1926; Esih 1928) a upozornil i na paralely, ktoré medzi Marínou a zbierkou Đulabije Stanka Vraza zachytil pol'ský slavista Władysław Bobek (Esih 1933).

J. Jankovič v druhom zväzku svojej monografie o chorvátsko-slovenských literárnych vzt'ahoch, ktorý sa vztahuje na obdobie rokov 1939-1948, teda na bezprostredne predvojnové, vojnové a bezprostredne povojnové obdobie, potvrdil prostredníctvom mnohých faktov o prekladoch z oboch strán intenzitu vtedajších chorvátsko-slovenských vzt'ahov, ale A. Sládkoviča ani raz nespomenul (Jankovič 2002). Ani chorvátskemu, ani slovenskému vojnovému kolaborantskému štátu nebolo Sládkovičovo všeslovansky orientované básnictvo po vôli, a ani komunisti v bývalej Juhoslávii jeho lyriku nevyužívali. Až do otvorenia univerzitných volitel'ných slovakistických kurzov v študijnom odbore bohemistika na Filozofickej fakulte v Záhrebe v roku 1994 a do otvorenia samostatného štúdia slovakistiky na tej istej fakulte v roku 1997 nebol v chorvátskej filológii a kultúrnom živote väčší záujem o prekladanie Sládkovičovej poézie. Sporadické preklady vychádzali najmä vo vydaniach miestnej českej a slovenskej národnostnej menšiny. Z tohto obdobia treba určite vyzdvihnút' krátky prehl'ad histórie slovenskej literatúry, ktorý pre edíciu Povijest svjetske književnosti napísal český slavista Dušan Karpatský, pretože Sládkoviča v ňom opísal ako vedúceho básnika celého slovenského romantizmu (Karpatský 1975). D. Karpatský sa zaslúžil aj o prvý celistvý chorvátsky preklad Sládkovičovej Maríny v roku 2005, ked'že Luko Paljetak, významný súčasný chorvátsky básnik, preložil Marínu práve na 
150

1972, v čase, ked' som ako člen Bábkového divadla Zadar bol na turné po Slovensku. Vždy som chcel preložit' toto jedinečné dielo. Museli však ubehnút' roky. Aj tak by k tomu nedošlo, keby som na tento svoj zámer nenahovoril kolegu a priatela, znamenitého prekladatel'a Dušana Karpatského, ktorému týmto aj tu d'akujem. Spoločnými silami, viribus unitis, trojica nadšencov, Andrej, Dušan a Luko, pokrikmi cez hustú romantickú hmlu tohto jedinečného a komplexného diela barda slovenskej literatúry prácu s potešením zavŕšili. Preto verím, že odteraz sa Andrej Sládkovič stane vd'aka Dušanovej, Lukovej a Bertovej pomoci [Bert, t. j. Albert Goldstein, editor knihy, pozn. M. Š.] aj chorvátskym básnikom, hodným porovnávania a oceňovania. Verím, že si jeho jedinečná Marína nájde svoje miesto medzi všetkými tými očarujúcimi devami a dámami, ktoré lámali srdcia a perá tol'kým chorvátskym básnikom a zaiste aj prekladatel'om“ (Paljetak 2005b).

L. Paljetak ako vynikajúci teoretik verša v doslove svojho prekladu dôkladne opísal, ako Sládkovič tvoril svoje strofy, a vysvetlil špecifiká svojich veršov vo vztahu k originálu, D. Karpatský v predslove obšírnejšie priblížil Sládkovičovo miesto v poézii slovenského romantizmu. Verše o Maríne ilustrovala v tomto vydaní svojimi grafikami akademická maliarka a grafička Zdenka Pozaić, pričom tak uzatvorila kruh s Paljetakom a Karpatským dôstojnou, hoci pomerne oneskorenou chorvátskou poctou Sládkovičovi. ${ }^{5}$ Prvý celistvý chorvátsky preklad Maríny tak vznikol z individuálnych afinít a inšpirácií chorvátskych umelcov.

Systematickejšie snahy o afirmáciu Sládkovičovej poézie sa spájajú so založením katedry slovakistiky na Filozofickej fakulte v Záhrebe. Jej zakladatel'ka, jazykovedkyňa a jedna z najplodnejších chorvátskych prekladateliek poézie zo slovanských jazykov Dubravka Sesar, ${ }^{6}$ vydala v roku 2008 so slovenským slavistom J. Jankovičom dvojjazyčnú zbierku Tatre $i$ Velebit, v ktorej sa popri slovenských origináloch nachádzajú aj chorvátske preklady veršov slovenských básnikov z 19. storočia, spolu s ich krátkymi životopismi (Jankovič - Dorotić Sesar 2008).Zbierka je cenným vyučovacím materiálom pre výučbu staršej slovenskej literatúry v študijnom odbore slovakistika v Záhrebe. Sládkovič je v nej zastúpený úryvkami z Paljetakovho prekladu Maríny, spomenutými básňami uverejnenými v časopisoch Slavonac a Nada a dvoma prekladmi D. Sesar - básňou Nehaňte l'ud môj a jednou strofou z epickej básne Gróf Mikuláš Šubić Zrínsky na Sihoti (Jankovič - Dorotić Sesar 2008: 78-95). Z tejto básne D. Sesar neskôr preložila dvadsat'sedem vybraných strof (Sládkovič 2016) a spolu s básňou Nehaňte l'ud môj a desiatimi strofami Maríny vo vlastnom preklade ich zaradila do svojej antológie slovenskej obrodeneckej poézie $S$ Tatra zove more moja čežnja (Dorotić

5 Z. Pozaić je prvou Chorvátkou, ktorá v roku 1997 preložila verše z Maríny - síce nie do chorvátčiny, ale do svojho vlastného umeleckého jazyka. Pre farebný drevoryt ju inšpirovalo úvodné venovanie Maríne (Venovanie) a toto venovanie, v slovenskom origináli a kaligrafickej forme s odtlačkom drevorytu, zaradila do druhého básnicko-grafického listu svojej bibliofilskej edície Riječ i slika (Pozaić 1997: 1-4).

6 Svoje preklady zväčša podpisuje aj dievčenským menom ako Dubravka Dorotić Sesar. 
Sesar 2018: 94-119), ktorá je koncipovaná podobne ako antológia Tatre $i$ Velebit (s originálmi, s prekladmi a so životopismi autorov).

Záverom možno zhrnút, že o Sládkovičovi sa písalo, paradoxne, viac v 19. storočí v chorvátskych populárnych periodikách určených na zábavu a poučenie, než neskôr, ked' sa jeho diela prekladali intenzívnejšie. Napriek menšiemu počtu prekladov Sládkovičovej poézie do chorvátčiny bolo chorvátskej kultúrnej verejnosti už v šest'desiatych rokoch 19. storočia známe jeho miesto v slovenskom literárnom kánone. Prekladatel'ská etapa chorvátskej valorizácie jeho diela pokračuje až začiatkom 21. storočia, Paljetakovým prekladom Maríny a prekladatel'skou aktivitou D. Sesar. Ako to zvyčajne býva s oneskorenými recepciami, tieto novšie preklady významnejšie zarezonovali len v pomerne úzkych akademických kruhoch, predovšetkým medzi slavistami.

Z chorvátskeho originálu preložila Mgr. Maja Novković.

Príspevok vznikol s podporou agentúry Hrvatska zaklada za znanost pre projekt IP-2018-01-2539.

\section{Archívne pramene}

Slovenská národná knižnica v Martine, Literárny archív, osobný fond Braxatoris-Sládkovič, Andrej, list Abela Lukšića Andrejovi Sládkovičovi, sign. M 94 A 52.

\section{Pramene}

KOLLÁR, Ján, 1868. Marinki. Sonet iz „Slavy dcere“. Dragoljub, roč. 2, č. 18, s. 278. KRAUS, Cyril, ed., 1970. Korešpondencia Andreja Sládkoviča. Martin: Matica slovenská. LIPA (národni zábavník vydal J. Viktorin), 1864. Slavonac, roč. 2, č. 19, s. 297-304.

MIROGOJSKI, 1864. Lipa. (Národní zábavník. Redaktor: Josip Viktorin, ročník tretí v Pešti 1864). Danica, roč. 18 , č. 11 , s. 84-87; č. 12, s. 93-95.

PJESME Andreja Sladkovića, 1899. Vienac, roč. 31, č. 46, s. 747.

PJESME Andrije Sladkovića, 1901. Vienac, roč. 33, č. 2, s. 38.

SLÁDKOVIČ, Andrej, 1864a. Na majčinom grobu. (Po slovačkom od Sladkovića M. M.). Slavonac, roč. 2, č. 4 , s. 49.

SLÁDKOVIČ, Andrej, 1864b. Prošnja. (Iz Slovačkoga od Sladkovića M. M.). Slavonac, roč. 2 , č. 6 , s. 81.

SLÁDKOVIČ, Andrej, 1895. Elegija. Slovački spjevao Andr. Sladković, preveo Josip Milaković. Nada, roč. 1, č. 6, s. 107.

SLÁDKOVIČ, Andrej, 1899. Spisy básnické Andreja Sládkoviča. SväzokI. Turčiansky Sv. Martin: Kníhkupecko-nakladatel'ský spolok.

SLÁDKOVIČ, Andrej, 2005. Marina. Sa slovačkog jezika, prema slobodnom prijevodu Dušana Karpatskog, prepjevao Luko Paljetak; grafike Zdenka Pozaić. Zagreb: Izdanja Antibarbarus.

SLÁDKOVIČ, Andrej, 2016. Knez Nikola Šubić Zrinski na Sigetu. Preveo Dubravka Dorotić Sesar. Forum, roč. 55, č. 10-12, s. 1078-1085.

SLAVNI slovački pjesnik Andrej Sladkovič, 1872. Vienac, roč. 4, č. 32, s. 515-516.

\section{Literatúra}

BREŠIĆ, Vinko, 2005. Čitanje časopisa. Uvod u studij hrvatske književne periodike 19. stoljeća. Zagreb: Matica hrvatska.

DOROTIĆ SESAR, Dubravka [SESAR, Dubravka], 1998. Recepcija slovačke filologije i slovačke književnosti u hrvatskome tisku 19. stoljeća. In KATUNARIĆ, Dražen, ed. Hrvatska/ Slovačka. Povijesne i kulturne veze (Slična sudbina i zajedničke osobnosti) = Chorvatsko-Slovensko: historické a kultúrne vzt'ahy (Podobný osud a spoločné osobnosti). Zagreb: Društvo hrvatskih književnika, s. 67-92.

DOROTIĆ SESAR, Dubravka, ed., 2018. S Tatra zove moja čežnja. Slovačko preporodno pjesništvo. Zagreb: Hrvatsko filološko društvo. 
152 ESIH, Ivan, 1926. Andrej Sladkovič. Slovački epos o hrvatskom Leonidi. Obzor, roč. 67, č. 306, s. 2.

ESIH, Ivan, 1928. Hrvatski motivi u slovačkoj književnosti (U epskoj poeziji: Grof Nikola

'o Šubić Zrinski od Andrije Sladkovića). Književnik, roč. 1, č. 1, s. 30-32.

হั)

ESIH, Ivan, 1933. Vrazi Sladkovič. Književna paralela izmedju „Djulabija“i „Marine“. Obzor, roč. 74 , č. 46, s. $2-3$.

@ JANKOVIČ, Ján, 1997. Chorvátska literatúra v slovenskej kultúre I. (do roku 1938). Bratislava: Ústav svetovej literatúry SAV.

JANKOVIČ, Ján, 2002. Chorvátska literatúra v slovenskej kultúre II. (1939 - 1948). Bratislava: Ústav svetovej literatúry SAV.

JANKOVIČ, Ján - DOROTIĆ SESAR, Dubravka, ed., 2008. Tatre $i$ Velebit = Tatry a Velebit. Bratislava: Vydavatel'stvo Jána Jankoviča.

KARPATSKÝ, Dušan, 1975. Slovačka književnost. In Povijest svjetske književnosti. Knjiga 7. A. Flaker, ed. Zagreb: Mladost, s. 79-114.

PALJETAK, Luko, 2005a. Andrej Sládkovič i njegova Marina. In SLÁDKOVIČ, Andrej. Marina. Zagreb: Izdanja Antibarbarus, s. 131-153.

PALJETAK, Luko, 2005b. Napomena prevoditelja. In SLÁDKOVIČ, Andrej. Marina. Zagreb: Izdanja Antibarbarus, s. 154.

PALJETAK, Luko, 2007. Andrej Sládkovič i njegova Marina. In PALJETAK, Luko. Vanjski rub. Studije i ogledi o stranim književnostima i književnicima. Zagreb: Naklada Ljevak, s. 79-96. POZAIĆ, Zdenka, 1997. Andrej Sládkovič: Marína [grafický list].Zagreb: vlastným nákladom. ŠABIĆ, Marijan, 2007. Češka književnost i kultura u hrvatskim književnim časopisima 19. stoljeća. Doktorska disertacija. Zagreb: Filozofski fakultet Sveučilišta u Zagrebu.

ŠABIĆ, Marijan, 2008. Iz zlatnog Praga. Češka književnost i kultura u hrvatskim književnim časopisima 19. stoljeća. Zagreb: Sveučilište u Zagrebu-Filozofski fakultet; Hrvatski institut za povijest - Podružnica za povijest Slavonije, Srijema i Baranje.

Dr. sc. Marijan Šabić

Hrvatski institut za povijest

Podružnica za povijest Slavonije,

Srijema i Baranje

Ante Starčevića 8

35000 Slavonski Brod

Hrvatska

E-mail: marijansabic@yahoo.co.uk 


\section{SIAWOWAC.

\begin{tabular}{|c|c|c|}
\hline \multicolumn{3}{|c|}{ Thastrilk i ureannik: Miroslav Kraljevic. } \\
\hline dina II. & U Požegii 10. veljače 1866 . & Broj 4. \\
\hline
\end{tabular}

\section{NA MAJČINOM GROBU.}

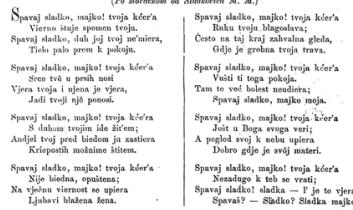

\section{PJESME PERZIJSKE}

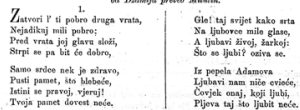

Obrázok 1: Obal časopisu Slavonac (10. február 1864)

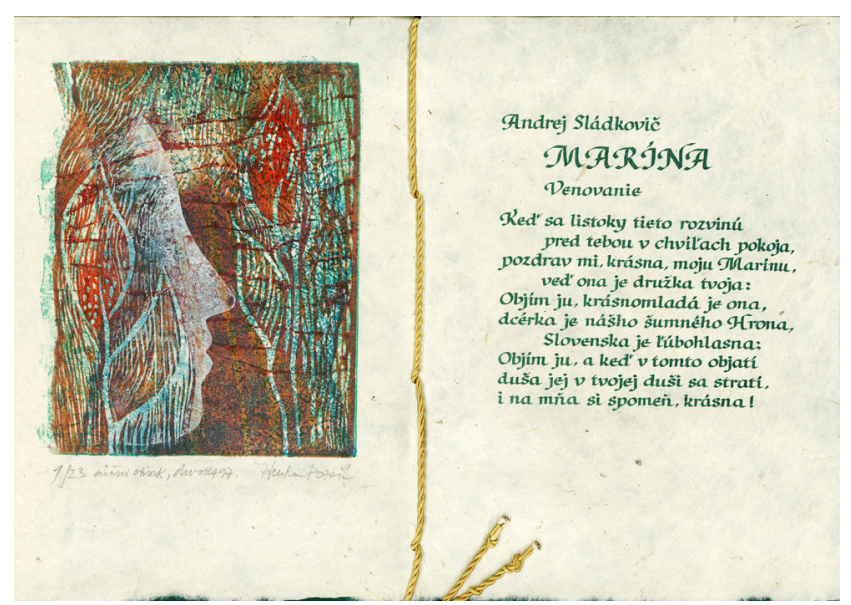

Obrázok 2: Marína, grafický list akademickej maliarky Zdenky Pozaić (1997)

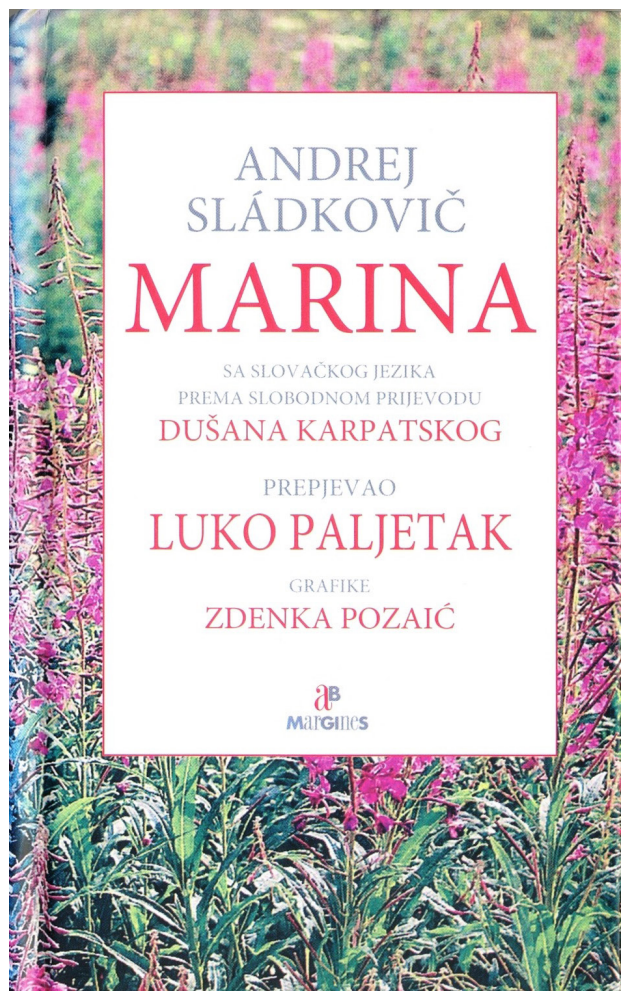

Obrázok 3: Prvý kompletný chorvátsky preklad Mariny (2005)

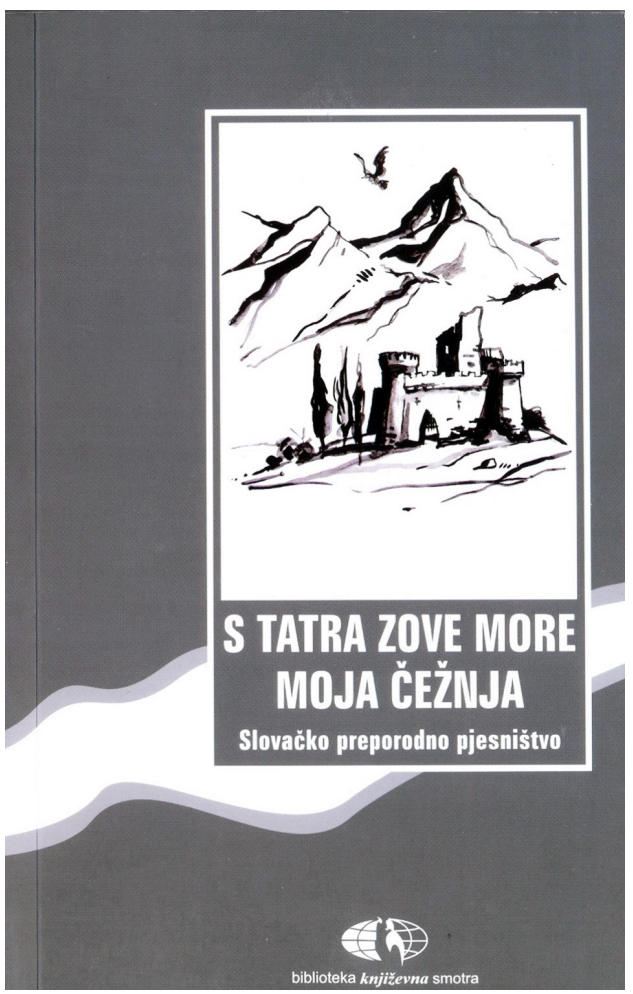

Obrázok 4: Chorvátska antológia slovenského obrodeneckého básnictva s prekladmi Dubravky Dorotić Sesar (2018) 